\title{
ЕТИКА
}

\section{UDC 101}

DOI https://doi.org/10.30970/PHS.2020.25-26.8

\section{CHANCES OF IMPLEMENTING KANTIAN IDEAS IN POSTMODERNISM}

\author{
Paulina Dubiel-Zielińska \\ Leopold Lis-Kula Secondary School № 2 in Rzeszów \\ Ks. Jałowego str., 22, 35-010, Rzeszów, Poland \\ e-mail:paulina.d@op.pl
}

The article is aimed at showing the possibilities of implementing Kantian ideas in the modern, defined as postmodern, world. Tries to answer the question about the place of duty and responsibility in this world.

The contents of the article include, respectively, the reflections on the specificity of postmodernism, particularly postmodern culture and image, the position of a human in this culture, an analytic and synthetic insight in Immanuel Kant's ethical thought; confronting the signs of postmodernism with I. Kant's idea for life, which attempts to prove that a genius, since purely formal, content of I. Kant's ethical law on the one hand partially demonstrates itself in the modern culture, and partially it should begin to be taken into consideration so that mankind does not lose itself in striving for Truth, happiness and an end in itself.

In relation to postmodernism, a new meaning of Truth is defined and its place in relation to Imagination and Tolerance. The image of postmodern culture is briefly outlined - its ambiguity, multicolor and specific blur.

Kantian ideas are described as belonging to the group of theories of principles in which principles are identified with duties. In the face of the necessity to take action, one can act either in accordance with the obligation (from a sense of coercion) or from the obligation, i.e. in the name of the obligation (from a sense of such need). The second line of reasoning seems appropriate, because it is acting in the name of good. This is what a truly free man does, i.e. he has the freedom to act within the limits of what autonomous principles require. In the postmodern world - in which corporeality and visuality reign and judging another person by appearance - this type of attitude seems to be the most appropriate due to its unwavering stability. in-itself.

Key words: Kantian ideas, Kant's ethical law, postmodernism, postmodern culture, truth, end-

\section{Characteristics of postmodernism}

Postmodernism, also known as postmodernity, liquid modernity, is described by Frederic Jameson as "cultural logics of late capitalism". This expression is usually identified with economic and politic transformations, particularly with the loss of an economic role of nations and takeover of their functions by transnational corporations; together with the decline of the colonial structure of economic dependency in favour of neo-colonialism based on cultural dependency and so-called "policy of identity"; and with immense transformations in the field of information, communication, perception of the world, and mostly a human currently dealing with the crisis of identity, autonomy, rationality and self-consciousness [8, p. 27-28].

Besides the facts mentioned one can also observe others, of a cultural nature: "collapse of the "great narrative", ideologies of domination legitimising the entire current political 
and social order (e.g. the ideology of progress, Western civilisational mission, Reason understood in enlightenment terms etc.), great aesthetic revaluations (the end of the division into "low" and "high" culture connected to a broader process of the collapse of authorities, basing on the popular culture texts, mostly referring to corporeality) and in the sphere of cultural means of communication (the dominance of visual culture), "the end of the culture of writing"), change of the way of perception and the social functions of science (generally - the collapse of the myth of scientific truth, the commercialisation of research)" [8, p. 28, 30, 37]. Postmodernism challenges understanding truth as an "accurate representation of reality" - the idea called "Truth" which could liberate us, does not exist - in this sphere a human is left on his own, while he gains freedom in reinventing himself [4, p. 98]. In the place of "Strive for Truth" one must put the ideals of "Imagination" and "Tolerance" [4, p. 100]. Tolerance, especially towards people holding different views, is the best solution since it broadens the horizons and it allows for learning more truths [4, p. 102].

Postmodernism feeds on ambiguity. The raison d'être is the borderline, marginality [7, p. 284]. Postmodernism appeals to a human to assume that he is only a human, fallible, historically determined and he cannot consider himself otherwise than as a participant of a conversation, who is equally important as other interlocutors [4, p. 101].

Abovementioned characteristic features could be encapsulated: in postmodernism culture has a number of meanings: one distinguishes between popular culture, visual culture, culture of body cult. Popular culture as a specific blend of styles, a shift from typical features of low and high culture, is free, sometimes even very loose in transmission, it is based on trends, fashion which oscillate around corporeality. There are no clear rules: fashionable and good is everything which can currently be sold, which is easily accessible, colorful, fast, comfortable, and omnipresent. However the trends are changing so each thing has its own short time after which it will be replaced with a new one - a better, newer, prettier, more comfortable, faster one. Humor and irony dominate in interpersonal relations. Everything must be taken with a pinch of salt. One should be able to maintain a healthy distance from oneself. There is no single truth: he is right who is able to sell himself and stand up for himself and his opinion.

Is there room for a critical philosophy in such a reality? Since culture is governed by ambiguity, comfort, liberty, tolerance, is there room for a duty and a sense of responsibility?

\section{Introduction to Kantian ideas}

Immanuel Kant's ethics is rationalistic and universalist. The scholar built it on the division of the world into a phenomenal (empirical) and noumenal (thing-in-itself) one which he had made by himself in the theory of cognition. In the phenomenal world - dominated by feelings, desires, needs, lust, drives - there is no room for morality. There is merely an egoistic inclination which could be naturalistically explained. Apart from it, in the world of phenomena one could detect the existence of moral law which commands that one acts against natural impulses - that is, follows the duty [conf.: 1, p. 187-188].

In the path-breaking ethics proposed by I. Kant there is one, the most important issue: going beyond relativism - the idea that there are no principles binding everyone. His ethics due to identifying universal precepts of moral functioning, comprises a certain legal construct [5, p. 19]: "Law [Gesetz] as a practical moral principle [Satz] includes the categorical imperative, that is a command" [2, p. 36]. "The categorical imperative, expressing an obligatory nature of certain actions is moral and practical law $<\ldots>$ " [2, p. 30]. Human "reason does not engage in $\langle\ldots\rangle$ a material aspect of law but only and solely in the form thanks to which an arbitrary maxim of an arbitrary will is able to become the universal law" [2, p. 18]. Will is arbitrary since it is not only and solely governed by a desire to achieve something, by sensual stimuli and inclinations, but most of all, by the supreme principles [2, p. 17-18]. "The principle of all 
principles" - since this is the name the categorical imperative could assume, is presented in a few versions, and the three of them are the most popular:

1. The Formula of the Law of Nature. Act only according to that maxim whereby you can at the same time will that it should become a universal law of nature [3, p. 38 ; see: 2 , p. 33 , 35, 389; see: 9 , p. 64].

2. The Formula of Humanity as an End in Itself: "Act in such a way that you treat humanity, whether in your own person or in any other person, always at the same time as an end, never merely as a means" [3, p. 46; see: 9, p. 64].

3. The Kingdom of Ends Formula: "Act according to maxims of a universally legislating member of a merely possible kingdom of ends" [9, p. 64].

The content of the discussed ethical law are of a purely formal nature since it expresses a very general conduct requirement and it can be formulated as the categorical imperative described above. The imperative - since it commands, categorical - since it does not inform what is to come if one thing or another is done but categorically commands that one acts in such a way, so that the action is worth emulating, becomes a model to be followed, a desired scheme of functioning. The categorical imperative is a priori and is rigidly autonomous since a human will itself imposes its ethical law on him [1, p. 188]. A will is free, it is a noumenal thing in the phenomenal world, it "is pure spontaneity, relatively an opportunity for making absolute beginnings" [1, p. 188], and the categorical imperative is its manifestation. In the phenomenal world there is no room for freedom, it is governed by the law (category) of causality, while the essence of a noumenal human is essentially freedom. The fact of realisation of this noumenon in the ethical world produces an unusual effect in the form of the phenomenon of morality [1, p. 188]. Morality is derived from the spiritual interior of a human, it is voluntary [1, p. 189].

\section{Chances of implementing Kantian ideas in postmodernism}

The realities of postmodernism prove that human rationality is in crisis but the idea of tolerance and openness which motivates all the actions and behaviours is becoming a safety gate protecting from stagnancy and moral agony.

I. Kant's rationalistic ethics emphasises not only the power of reason, but also its limits since the most essential in it is "God, Freedom and Immortality". One should deny knowledge in order to make room for faith - thereby I. Kant distinguishes between a starry sky and moral law and seeks for the meaning in both spheres (or beyond them) $[6$, p. 243, 244; see: 1 , pp. 186-187, 189]. I. Kant reconciles science and faith: "The existence of the outer world, completed by the causal links and an explanatory instrument of science are undoubtedly cognisable. At the same time, science does not impend the sphere of God and human soul immortality, as well as human freedom and moral duties" [6, pp. 243-244]. Knowledge and science govern the world - the world of senses, sensations, phenomena, appearances, experiences, empiricism, intuition. Apart from them there is freedom, morality, God and reason [6, p. 247]. " $<\ldots>$ without rational judgements our intuitions would be unquestioning. However without sensations our judgements are void. Experience is always an implementation of reason to sensations and the result of that is the world we know" [6, p. 244].

Therefore knowledge and science - according to I. Kant - are limited but simultaneously unlimited within their limits [6, p. 247]. The collapse of the myth of scientific truth - typical for postmodernism - seems to be consistent with that philosophical reasoning. Discovering the potential of human mind, technological and communication progress have increased the appetite of mankind for exploring the secrets of the world and all kinds of existence, thus an incalculable number of research - usually sponsored - which is aimed at discovering something, proving something or contradicting something. Moreover, in spite of the fact that the contemporary world is returning to the sphere of myths and magic, the questions whether 
God exists are on our minds and produce many alternative theories preceded by metaphysical research. Thus, both in the case of purely scientific and purely metaphysical research there is a remarkable convergence between Kantian ideas and the views of the postmodern world. Following it may lead a human to learning the Truth.

Now the attention should be drawn to the most significant sphere of humanity the sphere of human freedom which is related to what has been stated above. In postmodernism human freedom is considered selectively - as broadly understood liberty, following inclinations which frequently leads to crossing the permissive boundaries of; respect, taste, law, propriety etc. However promoting openness, in fact, cannot consist in tolerating everything and getting distant from that but in clearly indicating and objecting to perturbing phenomena. I. Kant's ethics comes to rescue: genuine freedom is not following inclinations but motivating oneself by the "power of will". People have a will that is free. Because of that, apart from being a part of the empirical (phenomenal) world - manifesting itself in the following natural inclinations and needs - they are a part of the noumenal (rational) world - expressing itself in the moral choices = in the resistance to inclinations. Noumenal existence guarantees a human partial independence from nature, an opportunity for adjusting his behaviour to his own law - moral law which creates his reason for himself. The groundwork of moral law is the categorical imperative "a single precept that is applied to a broad range of human behaviour" [6, p. 249], a requirement of an unconditional nature, binding on every rational being, not assuming any particular end but indicating ends in themselves, which are the outcomes of far-reaching actions [9, p. 63]. The categorical imperative in a universally important obligation (which results from recognising it as being a priori and synthetic). "Moral duties are categorical because one is a subject to them only due to a duty, only because they are obligations. $<\ldots>$ they are fundamental norms of deeds" $[9$, p. 63].

The mentioned categorical imperative formulas do not imply specific duties. They require, however, that one follows such maxims in one's life which could be recognised as being worthy of acting accordingly, that is on the one hand self-improving, and on the other hand - respecting the other human (his rationality) [6, p. 249]. Such a proposal of a duty seems to be extremely interesting in the times when the life philosophies, guidelines, advisors of how to act are not in short supply. The groundwork of I. Kant's moral law allows for a kind of arbitrariness but the one which is reasonable.

Morality and faith converge: realising the moral law does not require faith but obeying the law does. In order to persevere to obedience and dedication to morality one needs to believe that moral behaviour brings a human closer to happiness. Moreover faith, like morality, must be rational. What is more - reason guides a human towards religious faith and a conviction that moral behaviour eventually leads to moral good and happiness, understood as rational imperative which specifically means life after death [6, p. 249].

Therefore the return to Kantian rationality is salvation for a contemporary human since it may dispel numerous doubts related to the meaning of life resulting in moving away from God towards the sphere of myths and magic.

Finally, it is worth discussing the issue of corporeality - a highly significant "component" of human relationships in the postmodern culture. Corporeality seems to be a "relationship formation factor" on each stage of a relationship (personal, social, business), an independent variable of interpersonal relationships. Corporeality refers to the domain of aesthetics, beauty. But nowadays beauty is the same as the principle of "the best", mass produced by "show business". One must be the best - the prettiest, the slimmest, the most fashionable, etc. Such an image of a human is imposed by the fashion designers, advertising people, clothes producers, film industry, etc. Beauty is outside since fine feathers make fine birds. A human becomes "flat", 
"shallow", limited to natural instincts and impulses. I. Kant's philosophy comes to rescue since according to it "beauty is in the highest meaning the "symbol of morality"" [6, p. 250]. Thanks to this philosophy another human earns much respect in our eyes since he stops being perceived but he is contemplated [conf.: 6, p. 250]. Whilst we believe that "nature and we ourselves are a part of a far greater plan" [6, p. 250] we should try to ignore all the temptations and desires, we should not distract us by someone's personal charm but respect human dignity. Every aspect of the phenomenal world should be perceived in terms of pursuing a greater end, a broader dimension, described above [conf.: 6, pp. 250-251].

\title{
Conclusions
}

It is clear that on the one hand the characteristics of postmodernism are some kind of reflection of Kantian principles, and on the other hand Kantian ideas create a reliable guideline for mankind so that while pursuing modernity it does not lose what is the most important self-consciousness and consciousness what is really the end (in itself).

\section{References}

1. Bocheński J. Zarys historii filozofii. Kraków : PHILED, 1993.

2. Kant I. Metafizyka moralności / tłum. z niem. E. Nowak. Warszawa : Wyd-wo Naukowe PWN, 2005.

3. Kant I. Uzasadnienie metafizyki moralności / thum. z niem. M. Wartenberg. Warszawa : Wyd-wo Naukowe PWN, 1953.

4. Rorty R. Edukacja i wyzwanie postnowoczesności. Spory o edukacje. Dylematy $i$ kontrowersje we współczesnych pedagogiach. Warszawa : EDYTOR, 1993. S. 96-102.

5. Sole J. Kant: przełom kopernikański w filozofii / tłum. z hiszp. A. Paleta, B. Sosnowska. Warszawa : Kolekcja Hachette, 2018.

6. Solomon R., Higgins K. Krótka historia filozofii / thum. z ang. N. Szczucka-Kubisz. Warszawa : Wyd-wo Prószyński i S-ka, 1997.

7. Szkudlarek T. Pedagogie amerykańskiego postmodernizmu: edukacja wobec kulturowego przełomu. Spory o edukację. Dylematy i kontrowersje we współczesnych pedagogiach. Warszawa: EDYTOR, 1993. S. 284-300.

8. Szkudlarek T. Postmodernistyczne pedagogie: amerykańska edukacja wobec wyzwań kulturowego przełomu. Edukacja alternatywna - dylematy teorii i praktyki. Kraków : Impuls, 1992. S. 27-46.

9. Vardy P., Grosch P. Etyka / tłum. z ang. J. Łoziński. Poznań : Wyd-wo Zysk i S-ka, 2010.

\section{МОЖЛИВОСТІ ВТІЛЕННЯ КАНТІАНСЬКИХ ІДЕЙ У ПОСТМОДЕРНІЗМІ}

\author{
Пауліна Дубель-Зелінська \\ Школа Леопольда Ліс-Куля № 2 у Жешуві \\ вул. Кс. Ялового, 22, 35-010, м. Жешув, Польща \\ e-mail:paulina.d@op.pl
}

Стаття має на меті простежити можливості втілення кантіанських ідей у сучасній «картині світу», яку окреслюємо як постмодерну. Мета полягає в тому, щоб знайти відповідь на питання про місце обов'язку та відповідальності в актуальному сьогоденні.

Розглянуто міркування стосовно специфіки постмодерності, постмодерної культури і самосприйняття та поставу в ній людської особи; запропоновано аналітично-синтетичне переосмислення етичної думки I. Канта; зроблена спроба порівняти прояви постмодерності щодо розмислів німецького філософа про сенс людського життя й етичне існування. Доведено, що формальний зміст морального закону в концепції І. Канта, з одного боку, частково проявляється в культурі сьогодення, з іншого ж - кантівська концепція й надалі зберігає евристичний потенціал, який вартий бути 
предметом уваги та філософських і етико-правових досліджень, щоби людство не заблукало у своєму прагненні до Правди (Істини) і щастя як мети самої-в-собі. У контексті співвідношення кантівських філософсько-етичних ідей із постмодерністю запропоновано оновлене тлумачення визначення Правди (Істини), iіi ролі та значення порівняно з уявою і проблемою толерантності. Подано коротку характеристику постмодерної культури, виокремлено такі їі специфічні ознаки, як багатозначність, розмаїтість, своєрідну дифузну розмитість.

Ідеї і теоретичні принципи філософії Канта витлумачено в контексті його деонтологічної етики, в якій вони узгоджуються із внутрішнім для людини переживанням і прийняттям належного, що ототожнюється 3 обов'язками. Продемонстровано, що перед викликами необхідності людина може розпочати дію і чинити або згідно з обов'язком (з почуття внутрішнього примусу), або в ім'я обов'язку (з почуття такої потреби). Обгрунтовано, що цей другий варіант учинку можна вважати питомим для максими категоричного імперативу і властивим для дії в ім'я добра. Так чинить справді вільна, автономна особа, тобто така, яка усвідомлює свободу дії в межах засад незалежності. Продемонстровано, що в суспільному просторі постмодерної культури, де панують тілесність, візуальність і символічна реальність і обумовлене ними позірне сприйняття-оцінювання іншої особи, етична постава людини видається найбільш автентичною, зокрема з огляду на їі можливу непохитну стійкість.

Ключові слова: кантіанські ідеї, етичний закон Канта, постмодернізм, постмодерна культура, правда, мета сама-в-собі. 